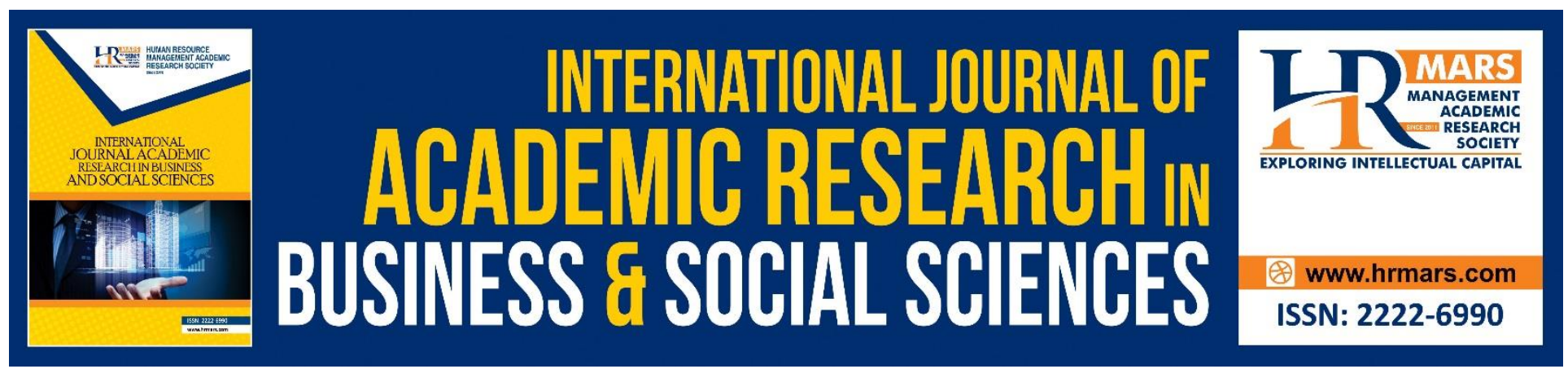

\title{
The Transition of Malay Political Culture in Terengganu: From Feudal, Neo-Feudal to New Politics
}

Ilyas Abdullah, Jamaie Hamil, Sity Daud, Nurul Saadatun Nadiah

To Link this Article: http://dx.doi.org/10.6007/IJARBSS/v8-i12/5394

DOI: $10.6007 /$ IJARBSS/v8-i12/5394

Received: 04 Nov 2018, Revised: 17 Dec 2018, Accepted: 26 Dec 2018

Published Online: 29 Dec 2018

In-Text Citation: (Abdullah, Hamil, Daud, \& Nadiah, 2018)

To Cite this Article: Abdullah, I., Hamil, J., Daud, S., \& Nadiah, N. S. (2018). The Transition of Malay Political Culture in Terengganu: From Feudal, Neo-Feudal to New Politics. International Journal of Academic Research in Business and Social Sciences, 8(12), 2070-2081.

Copyright: (C) 2018 The Author(s)

Published by Human Resource Management Academic Research Society (www.hrmars.com)

This article is published under the Creative Commons Attribution (CC BY 4.0) license. Anyone may reproduce, distribute, translate and create derivative works of this article (for both commercial and non-commercial purposes), subject to full attribution to the original publication and authors. The full terms of this license may be seen

at: http://creativecommons.org/licences/by/4.0/legalcode

Vol. 8, No. 12, 2018, Pg. 2070 - 2081

http://hrmars.com/index.php/pages/detail/IJARBSS

JOURNAL HOMEPAGE

Full Terms \& Conditions of access and use can be found at http://hrmars.com/index.php/pages/detail/publication-ethics 


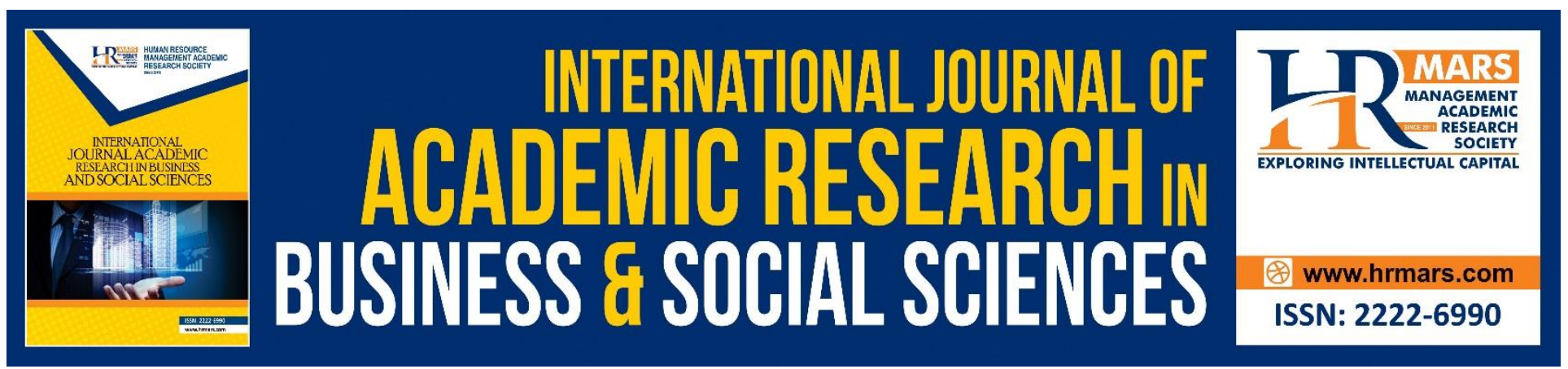

\title{
The Transition of Malay Political Culture in Terengganu: From Feudal, Neo-Feudal to New Politics
}

\author{
Ilyas Abdullah
}

Fakulti Sains Sosial Dan Kemanusiaan, Universiti Kebangsaan Malaysia

Corresponding Author Email: ilyasabdullah084@gmail.com

Jamaie Hamil

Fakulti Sains Sosial Dan Kemanusiaan, Universiti Kebangsaan Malaysia

Sity Daud

Fakulti Sains Sosial Dan Kemanusiaan, Universiti Kebangsaan Malaysia

\section{Nurul Saadatun Nadiah}

Centre for Foundation \& Languages Studies, Manipal International University, Nilai Campus

\begin{abstract}
This study discusses the transition of political culture of Terengganu Malay community which began from the time of the Malay Sultanate until the $13^{\text {th }}$ general election. Political culture of the traditional Malay society was feudal in nature. Sovereignty in the traditional Malay politics became absolute monarchs and nobility. The people claimed to shed completely loyal to the ruler. However, after independence, UMNO did often act as sultan in the modern era. This is because UMNO is the most powerful party in the context of Malaysian politics. UMNO often highlight his image as protector to the Malay interests through its economic development policies. Malays support for UMNO very strong and dominant. However four series of elections in Terengganu in 1999, 2004, 2008 and 2013 Malay political culture has entered a new politic when UMNO is no longer dominant in Terengganu. Both parties namely UMNO and PAS in particular have the opportunity to shape a balanced government in Terengganu.
\end{abstract}

Keywords: Political Culture, Malay Political Culture, Feudal, Neo Feudal, New Politics 


\section{Abstrak}

Kajian ini membincangkan transisi budaya politik masyarakat Melayu Terengganu yang bermula dari zaman Kesultanan Melayu sehingga ke pilihan raya umum yang ke-13. Budaya politik masyarakat Melayu tradisional adalah bersifat feudal. Kuasa pemerintahan dalam politik masyarakat Melayu tradisional menjadi hak mutlak raja dan golongan bangsawan. Rakyat dituntut untuk menumpahkan sepenuhnya ketaatsetiaan kepada pemerintah. Walaubagaimanapun, selepas mencapai kemerdekaan, UMNO pula seringkali berperanan sebagai sultan pada zaman moden. Hal ini kerana UMNO adalah parti yang paling berkuasa dalam konteks politik Malaysia. UMNO seringkali menonjolkan imejnya sebagai pelindung kepada kepentingan Melayu melalui dasar-dasar pembangunan ekonominya. Hal tersebut menjadikan UMNO terus disokong oleh rakyat sebagai pemerintah. Sokongan masyarakat Melayu terhadap UMNO juga begitu kukuh dan dominan. Walaubagaimanapun dalam empat siri pilihan raya terakhir di Terengganu iaitu pada tahun 1999, 2004, 2008 dan 2013 budaya politik masyarakat Melayu telah memasuki politik baru apabila UMNO tidak lagi dominan di Terengganu. Kedua-dua parti iaitu UMNO dan parti oposisi khususnya PAS dilihat mempunyai peluang yang seimbang untuk membentuk kerajaan di Terengganu.

Katakunci: Budaya politik, Budaya Politik Melayu, feudal, neo feudal, politik baru

\section{INTRODUCTION}

Terengganu Malay Sultanate has a unique history. Although most history books focused more on the Malaccan Malay Sultanates, the history of smaller governments like Terengganu is no less important. The socio-political structure of the Malay society can be expressed as a feudal society that is strongly loyal to the royal institution of the Malay Sultanate. The authority of the Sultan and the role of the religious leaders in the state's administration make Terengganu a long-lasting free and sovereign Malay state. However, political turmoil in the Malay states especially following the intervention of the British in Pahang has worried the Terengganu government in defending its sovereignty. Subsequently, Sultan Zainal Abidin III, with the advice from the state ruling chiefs drafted a law to strengthen the government's rule and sovereignty which was known as Itqan al-Muluk bi Ta'dil alSuluk (Hussain, 2014).

To face the pressure by the British that was seen as a threat to the Malay governance and sovereignty, Sultan Zainal Abidin III drafted Terengganu's State Constitution. The constitution was to protect Terengganu from outside influence. The Itqan al-Muluk was drafted on $2^{\text {nd }}$ November 1911 highlighted that the appointment of a state ruler must follow the guidelines based on the Quran. The Terengganu Constitution was drafted to maintain the sovereignty of Islam as well as ensure the prosperity of the state of Terengganu. Through the constitution, the Sultan of Terengganu managed to maintain the Malay and Islamic status of the state and prevented external influence namely from the British. The drafting of the constitution was in line with the political situation of the time, which saw the British greedily manipulate the state affairs in the Malay States. Terengganu's Malay political sovereignty was absolute and trumps the Sultan's power which was written in the $14^{\text {th }}$ clause of the Itqan al-Muluk which was paraphrased as:

“...Null and void any deals a ruler made to relinquish the 
state or the government or part of the government or the law to any other government or to other European powers. If the ruler tries to avoid or bypass this, thus he is considered to have broken the trust that was upon him" (Hussain, 2014).

The essence of the $14^{\text {th }}$ clause states that the state rulers are encouraged to build relationships with other powers namely the British. They were also urged by the British to receive British agents. Nevertheless, the rulers were forbidden to make any deals with any powers, western or otherwise, to hand over the state (Hussain, 2014). This policy proves the strong influence of Islam and the religious leaders in the state's administration.

\section{Transition of Political Culture: From Feudal to Neofeudal}

After the passing of Sultan Zainal Abidin III, the British finally succeeded in interfering with Terengganu's administration. The state administration was taken over by the Crown Prince, Sultan Muhammad. The reign of Sultan Muhammad failed to block the British interference. He signed an agreement with the British in 1919. The agreement was for Terengganu to receive a British advisor to oversee the state administration except matters related to Islam. This agreement made Terengganu the final Malay state that received a British advisor (Anuar, 2001). The presence of the British advisor in Terengganu shifted the monopoly of political power from the Malays to the British. The transition was evident with the introduction of the various enactments regarding land. To quell any uprising, the term of 'treason' was utilised by the British which was taken from the Malay feudal political system. Nevertheless, the presence of the British in Terengganu has given rise to open hostility from the Malays beginning in 1928. This showed that the Malays were smart to interpret that the word 'treason' used by the British is different from the term used by the rulers in the Malay feudal political system.

Bakar (1986) explained about the various laws and edicts specifically related to land matters which has generated discontent especially from the rural folk in Terengganu. Among the new laws introduced were the limitations placed upon the people from opening up new land. Anybody who wished to open up new land must acquire a permit from the Land Office with a fee of 50 cents annually. The enforced limitation also prohibited the population to open up new land and extract its resources without first acquiring a pass from the British. Nevertheless, the sultan had to accept the introduced laws. This situation caused the people of Terengganu to rise up and take a stand. According to Roff (1974), the people of Terengganu lost their faith on the sultan and the state rulers following their cooperation with the British.

After the Japanese surrendered to the Allied forces at the end of World War II, the Terengganu administration was placed under the administration of Terengganu's Senior Civil Affairs Officer. The British government introduced the Malayan Union. The introduction started a shift in the landscape of Malay politics from a radical-based resistance to a more political opposition. At the peak of all the anger and reactions, a large procession walked to Istana Maziah in April 1946. Protests were also 
happening all over Terengganu. After facing a series of protests, the British finally agreed to hold the inaugural State Elections on 29th October 1954, which was three months after the historic event at Padang Maziah. In the election, all 15 delegates from UMNO won over their opponents from Parti Negara and BEBAS. Since then, many UMNO branches were formed in Terengganu. In the inaugural Federal Elections on 27th July 1955, UMNO put forth its candidates in northern Terengganu which covered Kuala Nerus up to Besut, central Terengganu which covered Kuala Terengganu up to Hulu Terengganu, and in southern Terengganu which covered Dungun up to Kemaman. All three UMNO candidates easily defeated their opponents from Parti Negara with a huge majority. In the midst of UMNO's winning celebrations and formations of numerous branches, PAS began to enter the fray and spread their wings all over Terengganu. (Putera, 1996).

The head-on collision between the traditional political system and the colonial political system revealed a transition in the Malay political system as well as the institution. The power of the Sultan and the various royalties also experienced the change. The role of the Sultan in the state's administration and rule has been taken over by a new breed of Malays which consists of the administrative officers who are called the new administrative elite. The colonial political system also opened a new dimension by bringing in ideas of democracy such as parliaments, elections, and political parties. The early involvement of the Terengganu Malays in the elections and the formation of the political culture were driven by Islamic and Malay elements. UMNO received strong support in Terengganu following its effort to uphold the Malay sovereignty and the royal institution. Although there were other political parties participating in the 1954 and 1955 state elections, they failed to garner a strong support from the Terengganu Malays. However, the emergence of PAS in Terengganu in 1956 presented a rival to UMNO's influence, up until today.

\section{New Politics In Terengganu Post-10 ${ }^{\text {th }}$ General Election}

Sulaiman (2002) extensively analysed how, in the Malay Annals, a pledge between Demang Lebar Daun and Seri Teri Buana was used by the rulers to achieve powers without borders. According to the Malay Annals, a pledge was often used to keep the people in line and as a reminder of the offence of treason. A pledge was used as a tool to strengthen the status quo aside from paving the way for oppression to happen. In many instances, a pledge was used only for a ruler's self-interests, whereby the rights that protect the people from dishonour, oppression and punishment were easily erased. This results in the people not being so bold in questioning the biased interpretations of the law. What happened during the era of the Malay Sultanate was also happening in Malaysia's modern political context.

The introduction and use of acts, rules and state agents such as the police is often utilised by the rulers to strengthen the ruling hegemony. UMNO tends to reveal its antagonistic side (Jamaie, 2004) when they put academicians and civil servants in their crosshairs. Constructive criticisms aired by the academicians and civil servants towards the rulers were usually suppressed. These perceptions made the people who speak out look like dissenters and troublemakers, as well as a traitor to the rulers. This situation makes it seems like the freedom of speech that is contained in the Constitution was erased. Incidentally, the people were forced to submit and accept any decree from the rulers. 
However, in the current Malaysian political context, there are a few organisations that have begun to rise up and voice out their dissatisfaction of the oppression. The implication of this rise is that there are now various NGOs which exist as a reaction of the people to the rulers. This rise also influences the Malay political culture. Politics for politics' sake is no longer a part of their lives. Malays are now open to participate actively and practically in politics. The elements of universal values were loudly spoken. The rise of globalisation and the influence of ICT have expanded the Malay mind-set to become bolder, progressive and competitive. This elevated insight becomes the new culture in Malay politics. The importances of universal values are being accepted as well as becoming a dominant value in determining the attitudes and orientation of the Malay political society.

Sani (2000) explained that there is a clash between the practical politics of the 1960s and 1970s, and the new political culture born in the late 1990s. The political culture of the 1960s was still occupied with feudal elements and patronages. According to Rustam, the act of removing a political leader like Anwar by a ruling power would have a small possibility to create a long lasting crisis and a wave of political opposition. The 1998 political crisis saw a sense of unity and an act of close cooperation between the civil society and the political community. The presence of the civil society became a source of information to the people who are finally willing to challenge the status quo. This phenomenon was evident during the 1999 General Elections. Since the losing the votes in 1999, UMNO and BN still have not yet found a strategy or approach that could recapture the support of the people (Othman, 2008).

The shift in the Malaysian political landscape has witnessed the new wave that decorated the political shape and practice. Democracy is practiced more openly. The ruler-imposed democracy is fading. New politics has now taken the foothold as the common practice in the civil society. The hegemony that was utilised by the rulers to keep the status quo is slowly eroding when the society is open to reject leadership deemed irrelevant in the current political scenario. The 1998 political crisis due to the sacking of Anwar Ibrahim as the Deputy Prime Minister has sparked a new political movement (Sulastry \& Azila, 2013). This political movement highlighted the political protests by various elements in the society towards the government. The movement was made possible by the cooperation between the civil society and political community. The strong cooperation acted as an agent of change in making Malaysians realise their socio-political rights. The gatherings and the realisations of the people resulted in the rejection of UMNO and BN in the 1999 General Elections. This political upheaval has brought a rise of civil awareness (Weiss, 2003).

The Reformation movement was formed to make the people aware and demand a better freedom of democracy, economic revitalisation, and large-scale social revolution. The movement is an evidence of a dynamic political culture from racial politics to a new political culture where the people can join in through the created political space. The civil revolution is unstoppable by the government. The young Malays have been exposed to the new political culture through many ways. The peak of this civil movement leads to the formation of National Justice Party (KeAdilan). The formation of the party not only received support from the Malay middle class, but also from the non-Malays. This shows that the National Justice Party is a strong multi-ethnic party that shrinks the role of race politics 
that dominated Malaysia's partisan politics. The Malay political culture of the post-10th General Elections no longer revolved around the Malay Sovereignty and economy but has undergone a transformation and taken the concept of freedom, transparency, and human rights as the foundation of politics.

The formation of KeAdilan and other non-governmental organisations (NGOs) has created an alliance of opposition political parties to rival BN's hegemony and to pressure the government to govern fair and square. The demands of social and political awareness, freedom, justice and transparency became the main agenda. The dynamics of the Malay political culture can be seen clearly through the 1999 election results. The 1998 civil movement in Malaysian politics was more about the sacking and unfair treatment received by Anwar Ibrahim while in police detention. Anti-Mahathir sentiments also underlie the people's struggle to combat corruption and misuse of power as well as the desire of the people to have better and transparent governance. The political unrest that was happening made the people forget about their respective races' issues and vested interests, and focused on a more universal concern. This crisis also brought a new dimension of change in Malaysian political culture. Opposition parties which were seen as extremely Malay or extremely Chinese were now ready to form an alliance. The results of the 1999 General Elections saw BN lost in Terengganu and failed to retake Kelantan. The political crisis actually united the various races to fight for universal issues (Mayudin, 2014).

Since gaining independence in 1957, Malaysia was dominated by Barisan Nasional (BN) as the premier ruling party (Jali, 2006). This phenomenon represented the strong influence and hegemony of $B N$ upon the multicultural society and is tough to challenge by the idealism of some other political party. However, the 10th General Elections saw a challenger to BN's political hegemony and the rise of new politics. This development has weakened BN's domination and is seen as a process of democratisation in Malaysia's democratic system. The Malaysian political scene in the last two decades of the 20th Century has piqued the interest of many researchers to examine the appearance of new politics and universal elements in Malaysian politics. There were previous researches, such as by Kassim \& Ahmad (2002) who came up with the idea of new politics after looking at the 1999 General Election results, supported by further research by Loh \& Johan (2003).

Both premises were shaped by the observation of the perception and behaviour of the Malaysian political community post-10th General Elections. Fuad Mat Jali added that sociologically, they gave an indication that the expansion or development of Malaysian politics since two decades ago has seen the shape of the political culture shift from its usual norms. From the aspect of political culture, Malaysian politics usually contained elements of feudalism, or to some other observers, the concept of neo-feudalism. This particular type of political culture used a parochial code of conduct such as following orders without question, maintaining the status quo, undivided political loyalty and blindly accepting commands. However, the 1997-1998 financial crisis that shook East Asia and Southeast Asia triggered a regional political crisis and Malaysia was not spared. The leadership in Indonesia, Thailand, the Philippines and Taiwan repositioned to a younger leadership, free from the traditional and parochial political culture. On the other hand, the political reformation that was sweeping 
Malaysia was not enough to fully change the Malaysian political culture. Although the crisis did not spark a regime change like in Indonesia and Thailand, it did create a new political culture in Malaysian politics. The tone and focus of the struggle has shifted to new concerns such as demands for social justice, transparency in governance and decision making, effective management, responsible resource management and distribution, and opening up political space. For the first time in the context of Malaysian political development, these demands of democratisation are being deployed through political cooperation between the civil organisations and the opposition political parties. These developments have attracted the interest of Malaysian political observers to study this new political culture that is seen as a wave of democratisation, a wave which is a concrete demand of political culture.

In the 1999 Malaysian General Elections, BN's political hegemony was heavily threatened to the point that the election results that year was classified as the most significant turning point in Malaysia's political development (Jali, 2004). The results of the election that year clearly showed the erosion of BN's influence and political hegemony compared to previous years. Since the inaugural General Elections in 1959, UMNO-BN always managed to achieve a majority two-thirds win of the contested seats. In simpler terms, the 1999 General Elections saw UMNO-BN experienced drastic loss of votes, which indirectly visualises the erosion of BN's hegemony. The 10th General Elections in Terengganu saw BN suffered a loss of the popular votes until BN almost got booted out of the state. The 1999 General Elections was hotly contested due to the rising of civil awareness. The Malaysian civil society answered the call that can be heard throughout other developing countries. With the resurgence, the society is becoming more sensitive to the issues of civil rights, good governance, transparent government, corruption and misuse of power. History has seen how a ruling power who denies these civil liberties usually ends with their downfall. The fall of Pinochet, Marcos and Suharto and the harm that was inflicted to their economy and society was damaging and disgraceful. A political party in power will always have hegemony and plant a false awareness to its citizens. The ruling elite often laud the concept of integration and the Malaysian Race as an adjustment to the position of a national leader. Yet, at the local level and internally in the party, the issues of race, religion, and language continue to be the core struggle because these issues act as bait to get the votes. The ethnicities are still trapped trying to voice this sensitive issue within their own ethnic group while the voters gets unknowingly swayed and give their vertical support to their respective party leaders. They did not realise that this false awareness has been shaped by the ruling elite and were unaware that they have been hegemonised by this false awareness. It is disappointing when this situation is considered as the mainstream and that it is what democracy was thought to be (Sulaiman, 2005).

The wave of democracy that is sweeping many Asian and developing countries affects a country's economic development and its socio-political scene, also has an impact to its political development. People are beginning to realise the importance of basic rights as well as competition in democracy. Subsequently, civil demands are beginning to pop up with the various social and political movements. Malaysia is not immune to the process of social and political development. The effect of globalisation brings enlightenment. Previously, feudalism was strong in the minds of the people. Now, it is fading. The people now dare to question any unfair or unethical issues. The demand for truth is increasing 
(Huntington, 1993). The 1999 General Elections not only showed the opposition united, but also manifested a change in values and political norms of the society, to a more national value and political struggle, and leaving behind the primordial vales.

However, the 11th General Elections saw BN able to shrink the civil demands by cultural reorientation. The cultural re-orientation was an agenda by Abdullah Ahmad Badawi as soon as he took over leadership of BN in October 2003. Abdullah Ahmad Badawi tried to shave off the preconception of UMNO as a party rampant with nepotism in the administration. The win by BN due to cultural reorientation by Abdullah Ahmad Badawi however did not last long when a second political wave emerged stronger and able to rival the political wave of the 60s. This wave also affects Terengganu's political landscape which used to have a strong state government and in line with the federal government. However, the strong support enjoyed by UMNO in Terengganu is weakening. In power since 1961, UMNO shockingly lost to PAS in the 1999 General Elections. The support of the Malays to UMNO is also diminishing. Furthermore, the young voters also no longer choose UMNO. In the short time frame of four elections between 1999 and 2013, citizens of Terengganu have effectively utilised the elections to decide the rise or fall of a political party in the state. Political parties contesting in Terengganu now would feel the effect if there were any blunders in the elections (Agus, 2004). The political culture of the Malays in Terengganu changes drastically when Terengganu voters immigrate to other states and vote against UMNO and BN in the elections. The mega projects and rapid development in the Klang Valley and the west coast states were unable to sway their support in the elections. To the voters, public welfare is not only about enjoying progress and development from the government, but the government also has to provide a better and democratic social justice. The 12th General Elections in 2008 gave a big shock to Malaysia's political direction. This was due to the shift in the voter's political culture where the younger generation of voters acquire the political knowledge and information using alternative media (Fernando, 2011).

The younger generation in Terengganu seems less interested in the development agenda brought by $\mathrm{BN}$. Attendance of young voters to BN-organised speeches are shrinking. This is because young voters are more inclined to get information and alternative views about local and national issues from the opposition speakers. The young generation perceives that BN speakers have run out of ideas and usually resorts to issues of development and progress in their effort to gain the votes. Voters in Terengganu basically do not reject progress. Yet, the repetition of the issues of progress spoken by $\mathrm{BN}$ through the speeches and primetime media are seen as over the top. Terengganu voters perceive that the BN-organised speeches take a defensive position explaining the issues brought forth by the opposition. Nonetheless, the opposition speeches lean towards the offensive and demands explanations on the national and local issues. The opposition speeches are more about letting the voters think and evaluate BN's records in Terengganu. Local issues such as petroleum royalties, the construction of the Crystal Mosque, and the organising of the Monsoon Cup also interest the voters in Terengganu. 


\section{CONCLUSION}

Since the first elections after the Independence in 1959, the seat of the Federal Government has been retained by $\mathrm{BN}$. Before the $10^{\text {th }}$ General Elections, a BN sweep at the federal level and in almost all states was expected and is usually on point. Malays have been for a long time given the political support to the same political party, UMNO, which was a continuation of the feudal-based political culture. The Malays have given their continuous support for a long time to UMNO and BN even though they have other options in the the Malaysian political system since the elections were introduced. Yet, the results of the 1999 General Elections have shown that the Malaysian political landscape has entered a new phase. UMNO has lost the support of the Malays even when the party has the majority votes of the Malays. The coalition of the opposition is now seen as able to challenge BN's patron-based political hegemony. Furthermore, the coalition is able to rival BN's domination when they captured Terengganu in 1999 and won in other states in the 2008 and 2013 General Elections. Political culture not static but able to respond to the new ideas, whether it is generated in the system itself or received influenced from external influences. The relative stability of a political system depends on the ability of new attitudes to match into the structure of the existing value. The political culture approach helps communities to analyze the interaction between the political system and its culture. Traditional Malay political culture is associated with loyalty, adherence and also conformity to the leaders who compensated with protection. Loyalty is a value that governs the relationship between the rulers and the people, but is not absolute in nature. However, if the condition doesn't comply by the rulers, it will invite resistance from the people. This study is significant to explain the transformation of Malay political culture in Terengganu systematiclly and comprehensively. This is because political culture is very closely linked to the element of values, beliefs, emotions, traditions and history which affecting the political orientation of the community. In addition, this study is also able to enrich the corpus of knowledge in Malay political culture research in the modern political landscape in Malaysia.

\section{References}

Abdullah, A. B. (1986). Ke Arah Perlaksanaan Undang-Undang Islam di Malaysia: Masalah dan Penyelesaian. Kuala Terengganu: Pustaka Damai.

Agus, M. (2004). Politik Terengganu Selepas Pilihan Raya Umum 1999: Dari Royalti Ke Wang Ihsan. Jebat: Universiti Kebangsaan Malaysia.

Fernando, J. M. (2011). Pilihan raya Umum Malaysia: Isu dan Pola Pengundian. Universiti Malaya Press.

Hussain, N. H. (2014). Undang-Undang Bagi Diri Kerajaan Terengganu, 1911 dan Pengekalan Status Melayu Islam Terengganu: Jurnal Antarabangsa Dunia Melayu, Vol.7 (1), hal. 41-43.

Jali, F. M. (2004). Barisan Nasional Dan Hagemoni dalam Politik Malaysia. Kertas Kerja di Persidangan Antarabangsa Sains Sosial dan Kemanusiaan (iCOSH) 14-16 Disember 2004. Universiti Kebangsaan Malaysia. 
INTERNATIONAL JOURNAL OF ACADEMIC RESEARCH IN BUSINESS AND SOCIAL SCIENCES

Vol. 8, No. 12, Dec, 2018, E-ISSN: $2222-6990$ C 2018 HRMARS

Jali, F. M. (2006). Pilihan raya Umum Malaysia ke-11: Pendemokrasian Atau Reverse Demokrasi. Laporan Teknik Penyelidikan. Universiti Kebangsaan Malaysia.

Jamaie, (2004). Budaya Politik Melayu: Kesinambungan dan Perubahan. Dlm. Sity Daud \& Zarina Othman (pnyt). Politik Dan Keselamatan. Bangi: Penerbit Universiti Kebangsaan Malaysia.

Kamarudin, M. A. \& Jamaie. (2005). Budaya Politik: Perspektif Kepimpinan Politik Melayu Daripada Tradisi Ke Kontemporari. DIm. Maizatul HaizanMahbob \& Mohamad Zain Musa (pnyt). Tinjauan Baru Politik Malaysia. Bangi: Universiti Kebangsaan Malaysia.

Kassim, M. Y. \& Ahmad, A. (2002). Politik Baru Dalam Pilihan Raya Umum. Bangi. Universiti Kebangsaan Malaysia.

Loh, K. W. \& Johan, S. (2003). New Politics in Malaysia. Singapore: Institute of Southeast Asian Studies.

Mahmud, N. A. (2011). Tengku Ali, British dan Takhta Terengganu. Universiti Kebangsaan Malaysia. Jebat, Vol. 28, hal. 25-42.

Mayudin, G. (2014). Demokrasi Dan Pilihan Raya Di Malaysia. DIm. Ghazali Mahayudin, Jamaie Hamil, Sity Daud dan Zaini Othman (pnyt). Demokrasi Kepimpinan \& Keselamatan Dalam Politik Malaysia. Universiti Kebangsaan Malaysia: Bangi.

Othman, M. R. (2011). Pilihan raya Kecil Parlimen Kuala Terengganu 2009. Universiti Malaya.

Othman, Z. (2008). Masyarakat Sivil Dan Pendemokrasian. Dlm. Ghazali Mayudin (pnyt) Politik Malaysia: Perspektif Teori Dan Praktik. Bangi: Universiti Kebangsaan Malaysia.

Putera, S. (1996). Sejarah UMNO Terengganu 1946-1996. DIm. 50 Tahun UMNO Terengganu. Kuala Terengganu: Badan Perhubungan UMNO Negeri Terengganu, hal. 38-68.

Roff, W.R. (1974). Kelantan Religion, Society and Politics in a Malay. Kuala Lumpur: Oxford University Press.

Sani, R. A. (2000). Globalisasi, Krisis Dan Politik 1998. DIm. Norani Othman \& Sumit K. Mandal (pnyt). Malaysia Menangani Globalisasi: Peserta atau Mangsa?. Bangi: Universiti Kebangsaan Malaysia.

Sulaiman, N. (2002). Budaya Politik dalam Masyarakat Majmuk di Malaysia. Dlm. Abdul Munir Yaacob \& Suzalie Mohamad (pnyt). Etika dan Budaya Politik dari perspektif Islam.

Sulastry, N. \& Azila, N. (2013). Transisi Kontra Hagemoni Dalam Budaya Politik Melayu Di Malaysia. Universiti Malaya. 
INTERNATIONAL JOURNAL OF ACADEMIC RESEARCH IN BUSINESS AND SOCIAL SCIENCES

Vol. 8, No. 12, Dec, 2018, E-ISSN: 2222-6990 @ 2018 HRMARS

Weiss, M. (2006). Protest and Possibilities: Civil Society and Coalition for Political Change in Malaysia. California: Stanford University Press.

Zakaria, A. (1991). Perjuangan Orang Melayu Menentang British di Terengganu, 1909- 1957. Kuala Lumpur: Persatuan Sejarah Malaysia. 